\section{Reactors hit financial trouble}

FrANCE's ambitious nuclear programme has wound up in a curious dispute over the ownership of the chief reactor-builder, Framatome, in whose shares its chief rival, the Compagnie Générale d'Electricité (CGE) has acquired a controlling stake. The government is in a quandary over whether to renationalize Framatome.

This is an unexpected but unavoidable outcome of the past two decades, during which France has striven to make its nuclear energy industry second only to that of the United States. But now, with a slump in oil prices and a worldwide wariness after the Chernobyl accident, it has found itself with knowhow nobody wants and more electricity than it needs.

The 53 reactors belonging to the nationalized EDF (Electricité de France) - mostly of the pressurized water type, but including one fast-breeder reactor supply 75 per cent of the country's 342,000 million kilowatt-hours of electricity production. With very few coal, gas and oil resources, France began strengthening its nuclear capability during the 1970 s oil crisis. Successive governments continued the expansion policy, supported by a generally enthusiastic public.

France also has stakes in all aspects of the generation cycle. Cogéma, the industrial subsidiary of the Commissariat à l'Energie Atomique (CEA), the state research agency, has almost cornered the world market in irradiated fuel reprocessing at its La Hague plant on the coast of Normandy, on the English Channel, with a capacity intended to be 1,600 tonnes a year by 1992 and as much as 40,000 tonnes by 2000 .

Just as France's own construction programme matured, the Chernobyl accident led other countries to freeze their construction programmes, leaving France's two major manufacturers of nuclear technology, Framatome and CGE, with little hope of critical export orders. The situation was made worse by a saturated home market. In the $1980 \mathrm{~s}$, ten new reactors were commissioned to meet an expected demand that never materialized. And a new generation of fast-breeder reactors was planned to follow the experimental 1,200 MW Superphénix plant at CreysMalville on the Swiss border. But soaring costs, unreliability, cheap uranium and national overproduction led this programme to be shelved.

To add to the slump in enthusiasm for nuclear reactor construction, doubts have now been raised about the safety of existing reactors. Earlier this year, it was revealed that the wrong bolts had been used in maintenance on safety valves at the Gravelines site on the English Channel coast near the Belgian border. A report commissioned by EDF revealed
Crude oil refiners in France have been driven into a corner - and into research - by the nuclear energy industry, and by the collapse in the market for heating oil. Elf-Aquitaine, which operates three refineries in France, says that the annual throughput of crude has fallen from 100 million tonnes a year to only 80 million tonnes, and demand for heating oil has fallen even more drastically.

The problem is how to win a greater yield of saleable products, notably petrol (gasoline, otherwise essence) by the intelligent cracking of crude. The company claims to be a pioneer in the automatic control of refinery operations. Now, at its research laboratory at Solaize, south of Lyon, it has a team of eight people perfecting the operating parameters of catalytic petroleum crackers, believing that understanding will lead to a greater yield of lighter fractions.

The research programme has been a joint effort by Elf and CNRS since 1956. A group of four CNRS researchers have been seconded to the Elf laboratory. When their project finishes two years similar incidents elsewhere and that the risk of a major accident in the next 20 years at one of the French reactors could be much higher than previous estimates. There are six 1,300 MW reactors on the Gravelines site; even the remote threat of an accident has made France's neighbours twitchy.

But the need to replace old reactors, combined with expectations that industrial growth will increase energy demand in the next decade, means that the reactor construction programme is not dead. Only last week, EDF promised that a new $1,400 \mathrm{MW}$ reactor at Civaux would get the go-ahead next year after long delays.

The prospect of renewed growth has put Framatome and CGE at the heart of a political storm. Last month, CGE bought out shares in Framatome held by Dumez, giving it a 52 per cent of the company, a controlling stake. The government feels uncomfortable with its 45 per cent minority share ( 35 per cent CEA and 10 per cent EDF) and is now wondering whether to intervene by nationalizing Framatome again, so as to gain control over littlevalued but potentially critical expertise.

CGE, privatized in 1987, is against such a move and, in any case, nationalization is likely to run up against a ruling of the present government guaranteeing neither privatizations nor nationalizations of industries in the current mandate. Peter Coles better jobs.

\section{Science parks multiply}

RESEARCH may not immediately make nations prosperous, but it can do wonders for the prosperity of cities. That seems to be the principle on which several municipal governments are now working, from Lille and Rennes in the north and Lyon in the centre to Montpellier in the southwest.

So science parks are multiplying. At Montpellier, there are no fewer than three, conceptually centred on the city's intellectual assets.

The presence of IBM has stimulated the city, in the $1980 \mathrm{~s}$, to persuade small companies in informatique, robotics and artificial intelligence to what it calls its Parc du Millénaire.

Agropolis is the name for the similar effort in agronomy and agricultural biotechnology, the core of which is the complex of government laboratories with interests in food and agriculture, between them employing an estimated 1,800 people.

There is also what Montpellier calls its Euromedicine park, to which the city has attracted more than 20 businesses and research laboratories in the fields of pharmaceuticals and medical instrumentation.

What stands out from these endeavours is that the public laboratories are more than merely compliant, they are encouraging. It is public policy not only that France should increasingly rely on technology for its prosperity, but that neighbours with interests in research may be a source of research contracts, perhaps even of

\title{
Getting back to business
}

from now, the CNRS people will return to their laboratories not merely with a better appreciation of industrial problems, but with an expertise in the operation of large pilot plants. Nobody seems alarmed that they will also be the better able to advise Elf's competitors.

The problem of optimizing the design and operating parameters of a cat cracker is complex. J.R. Bernard, the Elf researcher who leads the group, likens it to the problems that arise in the design of nuclear fuel rods and the fixing of operating parameters.

The catalysts are zeolites, used in the form of $60-\mu \mathrm{m}$ grains which give the material the appearance of a brownishpink powder. Standard practice entails the use of heavier distillation fraction of the crude to support an upward-moving fluidized bed of catalyst in what is inevitably called a 'riser'. The cracking process appears to require as little as 2 seconds, which is a pointer to the speed at which materials are circulated through the plant. Petroleum products are stripped from the catalyst by steam and the catalyst recycled 